\title{
Historicizing the Ottoman Timar System: Identities of Timar-Holders, Fourteenth to Seventeenth Centuries
}

\author{
Linda T. Darling \\ University of Arizona \\ ldarling@email.arizona.edu
}

\begin{abstract}
This article aims to develop a new narrative of changes in the Ottoman timar system independent of the complaints of decline brought by advice writers like Mustafa 'Ali. Based on the icmal defterleri, it examines the identities of timar-holders and their changes over time, a topic generally ignored in descriptions of the Ottoman military. Using data from earlier studies, it connects changes in timar-holding with changing conditions in the sultans' reigns. It then takes a longer-term look at these changes over the half-centuries and finds the well-known complaints in the nasihatnameler to be based on a very short-term view of the system.
\end{abstract}

\section{Keywords}

Ottoman Empire - timar system - sipahi - icmal - mühimme - nasihat - ecnebi Mustafa Ali

The Ottoman empire's 'classical age' is known as an era when the empire's main administrative system, the timar system, simultaneously organized military life, political hierarchies, the social system, and the largest sector of economic production and distribution. ${ }^{1}$ By the reign of Süleyman Kanuni in the mid-sixteenth century, the timar system, the legal structure of kanun that

1 İnalcık, Halil, The Ottoman Empire: The Classical Age, 1300-16oo, tr. Norman Itzkowitz and Colin Imber (London: Weidenfeld and Nicolson, 1973). This paper was given in a different form at the CIEPO conference of 2015 in Budapest, at a panel organized by Douglas A. Howard and has benefited from those interactions as well as the comments of the anonymous readers 
regulated it, and the scribal officials who saw to the kanun's organization and implementation were regarded as the constituting institution of the empire. ${ }^{2}$ Alterations to the system, such as the granting of timars to outsiders, the decrease in the number of men-at-arms (cebelüs), the tax farming of timar revenues, and the chaotic administration and inadequate defense of the empire thought to result from these changes, were condemned by Ottoman critics writing advice works known as nasihatnameler. Narratives of the timar system, reflecting these works, have posited a 'classical age' in which a mature timar system flourished, followed by a period of detrimental changes contributing to the empire's fall. ${ }^{3}$ Some of the changes formerly ascribed to imperial decline have more recently been attributed to the price inflation of the sixteenth century and the 'military revolution', the replacement of cavalry forces armed with swords and bows by gun-bearing infantry. Still, the hidden assumption in both these formulations is that prior to those changes the timar system was conducted in adherence to sultanic edicts—-firm, stable, even static — and that this changelessness was a bulwark of the empire's strength. Descriptions of the system tend to conclude with Maria Alexandrescu-Dersca Bulgaru that with the changes of the late sixteenth century "the Porte precipitated the decline of the timar system, on which the military strength of the Ottoman Empire was based in the classical era". ${ }^{4}$

My longitudinal study of timar awards in the Ottoman summary registers (icmal defterleri), however, contradicts the assessment of the nasihatnameler. ${ }^{5}$

for this journal. It is not intended to be the definitive word on the timar system but to suggest an alternate narrative or narratives within which to frame future research.

2 Fleischer, Cornell H., Bureaucrat and Intellectual in the Ottoman Empire: The Historian Mustafa Âli (1541-16oo) (Princeton: Princeton University Press, 1986); Howard, Douglas A., "Ottoman historiography and the literature of 'decline' of the sixteenth and seventeenth centuries”, Journal of Asian History, 22 (1988), 52-77.

3 The most active perpetrator and influential exponent of this view has been Lewis, Bernard, "Some reflections on the decline of the Ottoman empire", Studia Islamica, 9 (1958), 111-27, but it has been very widespread among scholars as well as the general public. See, for example, Barkan, Ömer Lutfi, “Timar”, İslam Ansiklopedisi, vol. XII, pp. 286-333, or any of the standard textbooks.

4 Alexandrescu-Dersca Bulgaru, Maria M., "Sur la transmission du timar dans l'empire ottoman (xve-XVIe) siècles", in Türkische Wirtschafts- und Sozialgeschichte (1071-1920), ed. Hans George Majer and Raoul Motika (Wiesbaden: Harrassowitz, 1995), p. 9; see Cvetkova, Bistra, "Early Ottoman Tahrir Defters as a source for studies on the history of Bulgaria and the Balkans", Archivum Ottomanicum, 8 (1983), p. 180.

5 Darling, Linda T., "Nasihatnameler, İcmal Defterleri, and the Ottoman Timar-Holding elite in the late sixteenth century", Osmanlı Araştırmaları, 43 (2013), 193-226 (hereafter Nasihatnameler I) and Darling, Linda T., "Nasihatnameler, Icmal Defterleri, and the Ottoman 
It finds no unchanging classical system, no turning point after the death of Süleyman in 1566 or, according to Mustafa Ali, around 1580, and no subsequently dwindling or disappearance of timars, at least up to the end of the seventeenth century. ${ }^{6}$ The critiques in the literature of advice (nasihatnameler) claim that the corruption of the system began when timars were granted not to the sons of previous timar-holders but to people who were "outsiders" (ecnebiler). ${ }^{7}$ The question of the identities of these "outsiders" and the legitimacy of their receiving timars then become significant. The evidence of the Ottoman documents shows that the identities of timar-holders were changing constantly, not only in the late sixteenth century, and that their numbers did not diminish but increased. A new narrative is needed that incorporates these conclusions and correlates them with conditions in the empire. Most studies of the timar system focus on the numbers of timars, the status of the land, the taxpayers, and the revenue, while the identity of the timar-holders is a neglected question. ${ }^{8}$ The present paper sketches the observable changes in timar holding between the fourteenth and the seventeenth centuries and contextualizes them within two different possible narratives of the development of the timar system. This article does not aim to be the definitive work on timar-holders' identities (that will require much more extensive and detailed research), but rather intends to disturb the standard narrative, raise questions that have not yet been asked, and suggest a couple of alternate formulations.

The sources for such a narrative necessarily vary over time. For the fourteenth century there are only a few mentions in the chronicles, although

Timar-holding elite in the late sixteenth century: part II, including the seventeenth century", Osmanlı Araştırmaları, 45 (2015), 1-23 (hereafter Nasihatnameler II).

6 Contra Mustafa Ali, Mustafā 'Ālìs Counsel for Sultans of 1581: Edition, Translation, Notes, ed. and tr. Andreas Tietze, 2 vols., Philosophisch-Historische Klasse, 137, 158 (Vienna: Österreischschen Akademie der Wissenschaften, 1979, 1982). This result was also noted by Dávid, Géza, and Pál Fodor, "Changes in the structure and strength of the Timariot army from the early sixteenth to the end of the seventeenth century", Eurasian Studies, 4/2 (2005), p. 158; they corrected the description of the timar army on the Hungarian frontier in that period but did not generate a broader narrative.

7 Mustafa Ali, Counsel for Sultans, pp. 17-19, 84-86; Koçi Bey, Koçi Bey Risalesi, ed. Yılmaz Kurt (Ankara: Ecdad, 1994), pp. 47-52. See also Darling, Linda T., "The sultan's advisors and their opinions on the identity of the Ottoman elite, 1580-1653", in Living in the Ottoman Realm: Everyday Life and Identity from the $13^{\text {th }}$ to $20^{\text {th }}$ Centuries, ed. Christine Isom-Verhaaren and Kent Schull (Bloomington: Indiana University Press, 2016), pp. 171-81.

8 See, for example, İnalcik, Halil, An Economic and Social History of the Ottoman Empire, Volume One, 1300-160o, Halil İnalcık with Donald Quataert (eds.) (Cambridge: Cambridge University Press, 1994); Murphey, Rhoads, Ottoman Warfare, 1500-1700 (New Brunswick, NJ: Rutgers University Press, 1999). 
some of the sources that should be plumbed on the question of gaza might also prove helpful on the issue of early timars. ${ }^{9}$ From the fifteenth century on there are the icmal defterleri (summary registers listing all timar-holders in a province).$^{10}$ Although these registers may be problematic because of their summary nature and should be compared with the ruznamçe defterleri (daily records of timar bestowals), they conveniently indicate broader trends in timar-holding. From the sixteenth century on, mühimme registers (registers of outgoing orders), some of which are available in published form, can be added, as well as the aforementioned ruznamçe defterleri, which would well repay greater study, as they contain detailed information about the lives and careers of sipahis who received timars. ${ }^{11}$ Although the ruznamçe defterleri provide more complete data on specific individuals, the icmal defterleri include all the timar-holders of an area (usually by liva), not just those receiving timars or increases at a particular point, and so provide a clearer overall picture of who the timar-holders were over time. The ruznamçes occasionally attempt to be more complete, and there are also yoklama or inspection registers that cover the personnel of a particular campaign. ${ }^{12}$

From the icmal defterleri, on the assumption that they reflect the more detailed information in the ruznamçes, it is possible to calculate the percentages of timar-holders at any one time who were either sons of previous timarholders, slaves of the sultan, followers of great men of state, members of the provincial military or the administrative cadres, or who had no identifying title or patronymic. My study included holders of timars and zeamets but not of

9 See Darling, Linda T., "Reformulating the Gazi question: when was the Ottoman state a Gazi state?" Turcica, 43 (2011), 13-53, and the sources listed there.

10 Those in the Başbakanlık Osmanlı Arşivi can now be supplemented with the ones in the Oriental Section of the Bulgarian National Library and the Tapu ve Kadastro collection in Ankara; see Binark, İsmet (ed.), Bulgaristan'daki Osmanlı Evrakı (Ankara:T.C. Başbakanlık Devlet Arşivleri Genel Müdürlüğü, 1994). See also Afyoncu, Erhan, "Xvır. Yüzyıl Osmanlı Bürokrasisinde İki Yeni Defter: Cebe ve Derdest Defterleri”, Tarih İncelemeleri Dergisi, 15 (2015), 221-30.

11 See Howard, Douglas A., "The Ottoman Timar System and Its Transformation, 1563-1656", Ph.D. Dissertation, Indiana University, 1987.

12 The ruznamçes at the beginning of a sultan's reign contain a larger number of timars, because they include all those whose berats granting possession had to be renewed by the new sultan; however, according to a personal communication from Douglas Howard, these are listed in the order in which they were received, so they are mingled in with other requests. On yoklamas see Mutafčieva, Vera P., and Str. A. Dimitrov, Sur l'état du système de timar des XVIIe-XVIIIe ss. (Sofia: Éditions de l'Académie Bulgare des Sciences, 1968); Howard, "The Ottoman Timar System", pp. 154-8, 211-25. 
has. Their names often reveal their ethno-religious identities, while their titles refer to the offices they held, and Janissaries and members of the central and provincial military cadres are generally labeled as such. The presence of a patronymic reveals their status: if they were sons of timar-holders, at the time they petitioned for a timar they had to prove through documents and testimony that they were true sons of prior timar-holders or military officials. When they were originally entered into the defter, therefore, their fathers' names were known and were recorded as significant. According to Douglas Howard's research, the patronymics of sons of low-ranking soldiers such as sekbans, or of civilian officials, were usually not recorded, apparently because their fathers were not already in the timar system, so the patronymic distinguishes sons of timar-holders from sons of others. ${ }^{13}$ In previous studies I tracked changes in timar bestowal patterns over time using data from 49 icmal defterleri and other documents from the Başbakanlık archive as well as published registers, a sampling of those dated before 1560 and most of those from 1560 to the late seventeenth century (when the registers become few in number), with a concentration around 1580, when the major change was supposed to have occurred. ${ }^{14}$ They showed what all students of the timar system are aware of, that the system did not end in the late sixteenth or early seventeenth century but continued to exist and to function in some fashion through the seventeenth century and beyond.

The general conclusion to be reached from these registers is that up to the end of the seventeenth century (the scope of this study), timars did not disappear or even decrease in number overall, but decayed in some provinces and flourished in others and were held by different groups at different times for different reasons..$^{15}$ Nor did timar-holders lack military functions after the

13 Howard, "The Ottoman Timar System", pp. 170-2; see n. 18.

14 The sample spans the fifteenth-to-seventeenth-century time period at approximately ten to 15 -year intervals (depending on the vagaries of document preservation) and spatially covers the empire as a whole (Rumeli, Anadolu, and the Arab lands), but as much as possible stays clear of special situations (such as war zones, islands, or frontiers). Added to the archival sources were a number of published registers and data from registers; my thanks to the tireless librarians who helped in this endeavor. Data were drawn from the following registers in the Başbakanlık Osmanlı Arşivi: A.\{DFE.d.67, 81, 82, 170, 209; MAD10, 66, 129, 544; Ruz.17; ткмA333, 584; тт1m, 18, 66, 72, 86, 102, 139, 188, 193, 197, 212, 217, 258, $271,313,356,35^{8}, 371,390,421,469,471,544,548,553,562,590,601,613,661,677,728,765$, $730,732,735,837$. See below for further detail on these registers.

15 Many more local studies must be made to track these differences and determine their causes, but these studies must be situated in the larger context of the empire as a whole; the history of a single province or area cannot represent the history of the entire empire. 
'military revolution'; they continued to have roles in the siege warfare of the gunpowder era and in the protection and governance of the countryside and the borders. The previous narratives of the timar system, both the older one of a general decline after 1580 and the newer one in which the timar system was eclipsed by the military revolution and the switch to infantry with guns, must be reconsidered.

The current step toward a revised narrative centers on the question of who held timars at different points in the empire's history, with emphasis on the first half, and asks how the observable changes in timar bestowals can be linked to the larger historical issues of the period. In order to track change over time, I break the period into smaller segments and examine it in two different ways, first by sultan's reign, which might indicate changes in timar bestowals resulting from the policies or desires of different sultans or specific conditions during their reigns. This is followed by an analysis broken into 50-year periods in order to reveal longer-term trends in timar bestowals governed by conjunctural shifts. ${ }^{16}$

\section{Timar Bestowals in the Early Empire}

A history of the Ottoman timar system must begin in the early fourteenth century with the stories of awards by Osman (?-c. 1324) and Orhan (c. 1324-1362) to leaders of the gaza of large tracts of land, called timars by the fifteenth-century historians, which these leaders divided among their followers. ${ }^{17}$ We have no documentary records of this event or others like it, but they are narrated in the chronicles. The practice described there strongly resembles the Mongol

16 The length of these periods is somewhat arbitrary; the logic is that a century seems too long to reveal changes, but a 50-year period is longer than any individual sultan's reign.

17 Akgündüz, Ahmed, Osmanlı Kanunnameleri ve Hukuki Tahlilleri (Istanbul: Fey Vakfi, 1990), vol. I, p. 256; Aşıkpaşazade, Āshıkpashazādeh Ta'rīkhï: A History of the Ottoman Empire to A.H. 833 ( $A D$ 1478), ed. 'Ālī Bey (Istanbul: Matbaa-ı 'Āmire, 1914; rpt. Westmead, Eng.: Gregg International Publishers, 1970), pp. 20, 38. See Darling, Linda T., "The development of Ottoman governmental institutions in the fourteenth century: a reconstruction", in Living in the Ottoman Ecumenical Community: Essays in Honour of Suraiya Faroghi, ed. Vera Costantini and Markus Koller (Leiden: E.J. Brill, 2008), pp. 23-4; and the careful exposition by Mutafčieva, Vera P., Agrarian Relations in the Ottoman Empire in the $15^{\text {th }}$ and $16^{\text {th }}$ Centuries, East European Monographs (New York: Columbia University Press, 1988), pp. 7-16. Compare Fodor, Pál, "Ottoman Warfare, 1300-1453", in The Cambridge History of Turkey, Volume 1: Byzantium to Turkey, 1071-1453, ed. Kate Fleet (Cambridge: Cambridge University Press, 2009), pp. 195-9. 
iqtā'system said by the historian Rashid al-Din to have been instituted by Ghazan Khan $\left(1295^{-1303)}\right.$ to provide for fighters and their horses. ${ }^{18}$ In the beylical period, the frontier beys continued to hold and distribute their lands in a similar fashion, as did the frontier beys well into the fifteenth century. ${ }^{19}$ The individualized timar system known from later years appeared at the latest after the acquisition of the province of Hamid by Murad I (1362-1389), when he gave individual berats (authorization documents) to the existing timar-holders of Hamid. ${ }^{20}$ Timar surveys (tahrirs) began under Bayezid I (1389-1402), if not before; his surveys of conquered lands in Ankara and Albania indicate that he granted his followers timars in Anatolia as well as Rumeli. ${ }^{21}$

18 Rashid al-Din Fazlullah Habib, Jami'u't-Tawarikh: Compendium of Chronicles, tr. W.M. Thackston (Cambridge: Harvard University Department of Near Eastern Languages and Civilizations, 1998-1999), vol. III, pp. 730-5.

19 Beldiceanu, Nicoară, Le timar dans l'état ottoman (début XIVe-début Xvie siècle) (Wiesbaden: Ottoman Harrassowitz, 1980), p. 24; Grignaschi, Mario, "Les guerriers domestiques dans la féodalité turque”, VI. Türk Tarih Kongresi (Ankara: Türk Tarih Kurumu Basımevi, 1967), pp. 206-29.

20 Aşıkpaşazade, Āshıkpashazādeh Ta’rīkhī, p. 6o; Darling, "Development", p. 6. For Seljuk antecedents to this system see Köprülü, Mehmet Fuat, "Bizans Müesseselerinin Osmanlı Müesseselerine Te'siri Hakkında Bazı Mülâhazalar”, Türk Hukuk ve İktisadi Tarihi Mecmuası, 1 (1931), 165-313; Beldiceanu, Le timar, pp. 26-8; Cahen, Claude, The Formation of Turkey: The Seljukid Sultanate of Rüm: Eleventh to Fourteenth Century, tr. P.M. Holt (Harlow, England: Longman, 2001), pp. 103, 104-6; and for Byzantine antecedents see Lemerle, Paul, The Agrarian History of Byzantium: From the Origins to the Twelfth Century: The Sources and Problems (Galway, Ireland: Paul Lemerle, 1979), pp. 222-41; Ahrweiler, Hélène, "La 'Pronoia' à Byzance", in Structures féodales et féodalisme dans l'occident méditerranéen (Xe-XIIIe siècles): Bilan et perspectives de recherche (Rome: École française de Rome, 1980), pp. 681-9; Oikonomides, Nicolas, "The role of the Byzantine state in the economy", in The Economic History of Byzantium: From the Seventh through the Fifteenth Century (Washington, DC: Dumbarton Oaks Research Library and Collection, 2002), pp. 1042-50; Bartusis, Mark C., Land and Privilege in Byzantium: The Institution of Pronoia (Cambridge: Cambridge University Press, 2012). On an individual timar granted by Orhan see Beldiceanu, Le timar, p. 25 .

21 İnalcık, Halil, Hicrî 835 Tarihli Sûret-i Defter-i Sancak-ı Arvanid (Ankara: Türk Tarih Kurumu Basımevi, 1954), pp. xv, 103; İnalcık, Halil, "Arnavutluk'ta Osmanlı Hâkimiyetinin Yerleşmesi ve İskender Bey İsyanının Menşei”, Fatih ve İstanbul, 1/2 (1953), pp. 155-6; and İnalcık, Halil, "Ottoman methods of conquest”, Studia Islamica, 2 (1954), p. 109; see also Darling, "Development," p. 30 and n. 62; Beldiceanu, Le timar, p. 23 and nn. 42-6, pp. 24-5. The evidence consists of references in fifteenth-century registers to fourteenth-century surveys in Albania and Ankara; the first speaks of exemption documents (temessük) given to surveyed taxpayers by named officials who were beylerbeys of Rumeli under Bayezid, 
The Ottoman defeat by Timur at Ankara in 1402, the retaking of Ottoman lands by their former rulers, and their subsequent reconquest by different sons of Bayezid disrupted the timar system throughout Anatolia and Rumeli; as rule changed hands back and forth, so most likely did timars. During the period of civil war from 1402 to 1413 , Emir Süleyman is said to have continued the surveys in the areas he controlled; other princes and beys are also known to have granted timars. ${ }^{22}$ The recopying of a manual for the finance scribes in 1412 in Bursa reflects Çelebi Mehmed's support for administrative continuity. ${ }^{23} \mathrm{His}$ efforts to reconquer and reassemble the empire during his reign as Mehmed I (1413-1421) surely won support from those who had held timars under Bayezid and who stood to regain them from Mehmed.

This brief overview of the early period prompts three conclusions regarding timars: one, that the body of timar-holders in the fourteenth and very early fifteenth centuries consisted mainly of the warriors of the beys (not true in later times); two, that the beys must have been quite busy awarding timars to their followers, and that this activity contributed immensely to the development of Ottoman bureaucratic administration (and probably had a linguistic effect as well); and three, that in these decades the timars must have been the site of intense political contention between the followers of different beys. Such a contention has disappeared from our narratives of the period, which retain only the memory of a rivalry between the timar-holding families in general and the followers of the frontier raiders, the akıncıs, as these fighters and their leaders were politically marginalized.

The earliest extant timar register, dated $835 / 143^{-}-32$ and covering the Albanian province of Arvanid during the reign of Murad II (1421-1444, 14461451), suggests that after 1420 the timar-holding group was dramatically different from the picture painted above. ${ }^{24}$ In that register, only 20 percent of

the second of timars granted in Bayezid's time, and the third of a survey of Ankara by Timurtaş Paşa, its governor in 1396.

22 Beldiceanu, Le timar, p. 23, n. 40, on timars granted by Musa Çelebi and timars granted to the fathers and grandfathers of timar-holders active in 1464.

23 Nabipour, Mirkamal, Die beiden persischen Leitfäden des Falak 'Ala-ye Tabrizi über das staatliche Rechnungswesen im 14. Jahrhundert (Göttingen: Georg-August-Universität, 1973), p. 7; Darling, Linda T., "Ottoman accounting prehistory", in Proceedings of the ${ }^{\text {th }}$ World Congress of Accounting Historians, ed. Oktay Güvemli (Istanbul: Association of Accounting and Finance Academicians, 2008), vol. III, pp. 2421-33.

24 This register, TT1m, appears to be the only icmal from Murad II's reign. The next three registers, attributed in the catalog to Murad's reign, actually cover the early years of Mehmed II's reign: MAD525 bears the date 858/1454, and MAD250 and MAD303 are dated $859 / 1454-5$. 
timar-holders were sons of prior timar-holders, and few were sons of other great men. ${ }^{25}$ Nearly half ( 46 percent) were the sons of nobodies, their fathers' names not being listed in the register; these men were probably sons of lesser military men, scribes, or reaya. ${ }^{26} \mathrm{~A}$ full 22 percent were men recruited in the devşirme, janissaries and men holding palace positions, and another six percent came from the provincial governments' military forces. Thirty percent of the total were sipahis from the province of Saruhan, transferred there after a revolt in 1416 , and 13 per cent were non-Muslims. ${ }^{27}$ There is some overlap in these percentages. If this register represents Murad's timar bestowals, at this point in his reign he seems to have been displacing the sons of timar-holders in favor of people of lesser origins, whether because there were not enough sons of former timar-holders or because he wished to replace them with new men.

A sampling of the icmal defterleri for the next few decades reveals a pattern that changed with each succeeding sultan, although the extent to which each sultan personally guided these policies is unknown. If there was a classical 'system', it was not very systematic. Mehmed II (1444-1446, 1451-1481) is considered unusual for favoring graduates of the palace school over men who rose through the timar system, appointing men from the devşirme into the grand vizierate and other high offices. It would be natural to assume that he continued or even increased the awarding of timars to janissaries, but the evidence contradicts this assumption. A sample of the extant timar registers from his period showed an average of only three percent of the timar-holders as janissaries, compared to 22 percent in the 1431 register. ${ }^{28}$ Thus, it appears that the ordinary men of the devsirme were considerably less favored than the graduates of the palace school, whom Mehmed promoted to high office. Forty-six percent of timars were held by sons of timar-holders, which in addition to policy could reflect

25 Mutafčieva, Agrarian Relations, p. 38, lists even lower percentages of sons of timar-holders for later entries in the 1431 register and for other undated fifteenth-century registers.

26 See Howard, "The Ottoman Timar System", pp. 170-2.

27 İnalcık, Hicrî 835 Tarihli Sûret-i Defter-i Sancak-ı Arvanid. Until 1520 there were provinces where Christian timar-holders numbered up to 16 percent of the total, and there were a few even into the seventeenth century; Darling, "Nasihatnameler I," p. 203; thus, the idea that Christian timar-holders vanished at the end of the fifteenth century must be revised. For a list of the earliest surviving registers of different locations in Anatolia see Çiçek, Kemal, "The earliest population and fiscal surveys (Tahrir Defterleri) for the Anatolian provinces of the Ottoman empire", оTAM, 7 (1996), 45-97.

28 The registers used from Mehmed II's reign are MAD10 Tirhala 859/1454, MAD 554 Serbia 859/1454, and MAD 66 Tirhala 873/1468. All figures other than Soyudoğan's are rounded off from Darling, "Nasîhatnameler I", pp. 21-21. They are only a sample; a more detailed study of this period using other registers might alter these figures somewhat. 
a higher rate of survival and reproduction by sipahis during Murad II's reign than during the Interregnum. ${ }^{29}$ Registers from Tirhala and 'Serbia' dated 1454 show an average of 36 percent of timar-holders coming from the provincial government's military forces, from the retinues of beylerbeys and sancakbeys, while 25 percent or more were Christians. ${ }^{30}$ In the following year nearly 40 percent of the timars of Vidin were granted to provincial military forces: fortress guards (including martolos, Christians), gunners, and falconers. ${ }^{31}$ Mehmed II also enacted measures increasing central control over the bestowal of timars. ${ }^{32}$

Another register from Tirhala in 1468 shows a distinct change in awards; it contained no timar-holders from the provincial military and a only handful of followers of other great men, together with a much reduced number of Christians, but the highest number of sons of timar-holders in the period, 75 percent. Throughout Mehmed's reign, timar-holding sons of nobodies declined from the 46 percent of Murad II's reign, initially to about 20 percent and later to only four percent. In none of these registers were timar-holders of devşirme origins significant. This pattern suggests that Mehmed may have been trying either to attract his chief military men by patronizing their followers, or to weaken them by bringing their men into his own service (or both, perhaps), and that later on he showed favor to the sons of timar-holders, but not to janissaries or the sons of other reaya. As we know, to placate these sons of timar-holders and recruit them for his army he had to take land away from zaviyes and akıncıs; we

29 Thanks to Douglas Howard for the suggestion that the birth rate among timariot families was a relevant factor; Howard, "The Ottoman Timar System", pp. 178-82.

30 The designation 'Serbia' was given to this register by Šabanović, Hazim, Krajište IsaBega Ishakovića: Zbirni Katastarski Popis iz 1455. Godina/Hicri 859 Tarihli Suret-i Defter-i Mücmel-i Vilayet-i Yeleç ve İzveçan ve Hodidide ve Seniça ve Ras ve Üsküb ve Kalkandelen me'a Tevabiiha (Sarajevo: Orijentalni Institut u Sarajevu, 1964). See also Soyudoğan, Muhsin, "Reassessing the Timar system: the case study of Vidin (1455-1693)", Ph.D. Dissertation, Bilkent University, 2012, p. 141; İnalcık, Halil, "Timariotes chrétiens en Albanie au XV. siècle d'après un register de timars ottomans", Mitteilungen des österreichischen Staatsarchiv, 4 (1951), 118-38; Cvetkova, "Early Ottoman Tahrir Defters", pp. 16o-7 and nn. $63^{-5}$. In a 1469 register over one-fourth of the timars were assigned to Christians: Oruç, Hatice, "Christian sipahis in the Bosnian Sandjak ( $15^{\text {th }}$ Century)", Archivum Ottomanicum, 26 (2009), 5-16; a late fifteenth-century register for Vidin showed 18 percent Christians: Gradeva, Rossitsa, "Between hinterland and frontier: Ottoman Vidin, fifteenth to eighteenth centuries", in The Frontiers of the Ottoman World, ed. A.C.S. Peacock (Oxford, New York: Oxford University Press, 2009), pp. 337-45.

31 Soyudoğan, "Reassessing the Timar System", pp. 185, 193, 296, 299, 301.

32 Káldy-Nagy, Gyula, "The first centuries of the Ottoman military organization", Acta Orietalia Academiae Scieniarum Hungaricae, 31/2 (1977), pp. 153-4. 
shall see what happened to the timar-holders' sons when Bayezid II returned these lands.

The janissary element among the timar-holders now appears smaller than was formerly estimated by extrapolation from the earliest register. The number of janissary timar-holders in Murad II's reign proved not to be typical of later periods. More timars went to sons of timar-holders even prior to Mehmed's "reform" than we used to think. ${ }^{33}$ The frontier forces were definitively out of power by the later fifteenth century, and the revenues of lands held as mülk and vakıf by frontier commanders were diverted to supporting timar-holders and men-at-arms drawn not only from the sons of timar-holders but from the official provincial forces as well. ${ }^{34}$ The political struggle now lay between the timar-holders (most of whom were not former Janissaries) and the Janissaries (most of whom were not timar-holders), but there was a third significant force, the provincial military (whether Muslim or Christian, tied to the political hierarchy or autonomous non-akıncı forces), a number of whom did hold timars. While they apparently had no role as such in the political rivalries of the capital, it seems that their role in the empire as a whole was not as negligible at this time as it previously appeared. They should be investigated, as they are probably among the men who later became the forces of the ayan and derebeys; the timar records offer an opportunity to study their early development.

The timar awards made under Bayezid II (1481-1512) and Selim I (1512-1520) differed from both Mehmed's and Murad's, but they showed some trends that would be repeated under their sixteenth-century successors, with the notable exception of Süleyman. The revenues that Mehmed II had diverted to the timar system were subtracted again under Bayezid II for restitution to their previous owners (in most cases), but their return did not restore to the owners their former political importance. Only around 20 percent of timar-holders under these two sultans were sons of prior timar-holders, a considerably lower

33 A fragmentary register for Vidin dated 1477 showed 85 percent of timar-holders as sons of previous timar-holders; Bulgarian National Library St. Kiril and St. Methodius, OAK $265 / 27$.

34 Cvetkova, Bistra, "Sur certaines reformes du régime foncier au temps de Mehmet II", Journal of the Economic and Social History of the Orient, 6 (1963), 104-20; Beldiceanu, Nicoară, "Recherches sur la réforme foncière de Mehmed II", Acta Historica, 4 (1965), 25-39; Mutafčieva, Vera P., "De la politique interieure de Mahomet II le Conquérant", Studia et Acta Orientalia, 5-6 (1967), 253-65; Mutafčieva, Agrarian Relations, pp. 131-4; Arıkan, Zeki, XV-XVI. Yüzyıllarda Hamit Sancağı (Izmir: Ege Üniversitesi Edebiyat Fakültesi, Tarih Bölümü, 1988); Özel, Oktay, "Limits of the Almighty: Mehmed II's 'land reform' revisited", Journal of the Economic and Social History of the Orient, 42/2 (1999), 226-46. 
figure than under Mehmed or Süleyman. ${ }^{35}$ Even in the reduced timar system of Bayezid and Selim, then, sons of timar-holders held a diminished place. This reduction in the role of timar-holders' sons surely explains the agitation in the early sixteenth century over the granting of timars to "outsiders". ${ }^{36}$ About ten percent of timar-holders on average were from the devşirme or palace slaves, a number that was higher than the level under either Mehmed II or Süleyman and more like the figures for Süleyman's successors. ${ }^{37}$ Less than five percent were from the provincial military forces. The sons of nobodies crept upward to 30 percent (one wonders how many of them were sons or grandsons of dispossessed timar-holders), and that figure would continue to increase for the next two centuries. This pattern is still observable at the very beginning of Süleyman's reign, although it was soon to change. Apparently the 'classical' system was less classic, as well as less systematic, than either we or the Ottoman advice writers believed.

\section{The 'Classical' Timar System of Süleyman's Reign}

The reign of Süleyman $\left(1^{20-1566)}\right.$ was when timar-granting and timarrecording procedures were regularized and the timar system gained its full 'classical' character. ${ }^{38}$ His centralization efforts are better-known than those of

The registers employed for these reigns were TT18 Bosna 890/1485 and TT66 Aydın, Menteşe 924/1518. A fragmentary register for Kırkkilise dated 1483 also shows 25 percent of timar-holders as sons of previous timar-holders; Bulgarian National Library St Kiril and St. Methodius, OAK 18/17.

36 See Káldy-Nagy, Gyula, “The 'Strangers' (Ecnebiler) in the 16th century Ottoman military organization", in Between the Danube and the Caucasus, ed. György Kara (Budapest: Akadémiai Kiadó, 1987), pp. 165-9; Mutafčieva, Agrarian Relations, pp. 134-5; Darling, "Nasihatnameler I", p. 199.

37 But see a register for Trabzon in 1486 described by Barkan, where out of 207 timars, 101 or almost half were granted to slaves of the sultan; Barkan, Ömer Lütfi, "Osmanlı İmparatorluğu'nda Bir İskan ve Kolonizasyon Metodu Olarak Sürgünler (III)", İstanbul Üniversitesi İktisat Fakültesi Mecmuası, 15/1-4 ((Ekim 1953-Temmuz 1954), p. 217, rpt. in Barkan, Ömer Lütfi, Osmanlı Devletinin Sosyal ve Ekonomik Tarihi: Tetkikler - Makaleler, ed. Hüseyin Özdeğer (Istanbul: İstanbul Üniversitesi İktisat Fakültesi Yayınları, 20oo), p. 586 . This register brings the average of awards to palace slaves under Bayezid and Selim up to nearly one-fourth, which was thought to have generated rebelliousness among the sons of timar-holders; Barkan, Ömer Lütfi, “Timar”, İslam Ansiklopedisi, vol. XII, p. 301.

38 For Süleyman's legislation governing inheritance within the timar system see BeldiceanuSteinherr, Irène, "Loi sur la transmission du timar", Turcica, 11 (1978), 78-102, and Howard, Douglas A., "Ottoman administration and the Tîmâr aystem: Sûret-i Kânûnnâme-i 'Osmânî Beray-i Tîmâr Dâden”, Journal of Turkish Studies, 20 (1006), 46-125; for his 
TABLE 1 Timar-holders' Origins (Average Percentages)

For reasons of space, this table omits the sons of administrative personnel, other identifiable military groups, and high officials, so the percentages do not equal 100.

\begin{tabular}{llllll}
\hline Sultan & $\begin{array}{l}\text { Sons of } \\
\text { timar-holders }\end{array}$ & $\begin{array}{l}\text { Janissaries, } \\
\text { gilman }\end{array}$ & $\begin{array}{l}\text { Provincial } \\
\text { military }\end{array}$ & $\begin{array}{l}\text { Followers of } \\
\text { great men }\end{array}$ & $\begin{array}{l}\text { Sons of } \\
\text { nobodies }\end{array}$ \\
\hline Murad II & 20 & 22 & 6 & - & 46 \\
Mehmed II & 46 & 3 & 24 & - & 14 \\
Bayezid II-Selim I & 19 & 10 & 2 & 2 & 30 \\
Süleyman & 49 & 6 & 3 & 6 & $16 / 25$ \\
Selim II & 20 & 4 & 3 & 3 & 61 \\
Murad III & 40 & 7 & 3 & 3 & 38 \\
\hline
\end{tabular}

Sources: Darling, Linda T., "Nasihatnameler, İcmal Defterleri, and the Ottoman Timar-holding elite in the late sixteenth century", Osmanlı Araştırmaları, 43 (2013), 193-226; Darling, Linda T., "Nasihatnameler, Ícmal Defterleri, and the Ottoman Timar-holding elite in the late sixteenth century: Part II, including the seventeenth century”, Osmanlı Araştırmaları, 45 (2015), 1-23.

Mehmed II, but even during his time many timar-holders seem to have been on lands that they held by tradition or inheritance rather than assignment. In other respects his timar awards differed from those of some of the other sultans. In Süleyman's reign, almost half the timars went to sons of timar-holders, although this proportion varied widely from place to place and from year to year, going as high as 93 percent and as low as ten percent. ${ }^{39}$ Only six percent of timars were granted to the men of the devşirme, although later in his reign

regulation on surveys see Beldiceanu-Steinherr, Irène, and Beldiceanu, Nicoară, "Règlement ottoman concernant le recensement (première moitié du xvie siècle)", SüdostForschungen, 37 (1978), 1-40. For an analysis see Grignaschi, Mario, "Das osmanische timar-Recht und der kanun Süleymans des Gesetzgebers", in Armağan: Festschrift für Andreas Tietze, ed. Ingeborg Baldauf and Suraiya Faroqhi (Prague: enigma corporation, 1994), pp. 123-36. These figures contradict the idea expressed by Röhrborn and drawn from the kanun that timars went overwhelmingly to the sons of previous timar-holders by right; Röhrborn, Klaus, Untersuchungen zur osmanischen Verwaltungsgeschichte (Berlin: Walter de Gruyter, 1973), pp. 29-32.

39 The registers employed for Süleyman's reign were тт371 Karaman 926/1520, тт390 Mora 926/1520, тT421 Trablusşam 926/1520, тT102 Manisa 927/1521, тT139 Aydın 934/1527, тт72 Manisa 938/1531, тт188 Beyşehir 943/1536, тт193 Bosna 946/1539, тт197 Erzurum 946/1539, тт217 Paşa 949/1542, тт271 Haleb 957/1550, тт313 Haleb 966/1538, тт469 Avlonya 967/1559, TT548 Trablusşam 968/1565, Ruz.17 Aydın 971/1563, Malta Campaign Register 972/1564, тт356 Lipova 973/1565, тт86 Bolu 973/1565, тт358 Diyarbekir 973/1565, 
higher figures appeared; and the officer corps came increasingly from the palace school. ${ }^{40}$ So far this resembled Mehmed II's pattern, but the provincial military were only granted three percent of the total, with slightly higher figures appearing in the years after Prince Bayezid's rebellion. With few exceptions, administrative personnel held five percent or fewer of the timars, as did followers of men of state in most registers. ${ }^{41}$ Sons of palace slaves amounted to two percent, and sons of nobodies dropped to 16 percent for most of Süleyman's reign, although a few higher figures at the beginning and end brought the average to 25 percent. Süleyman's cadre, despite the heavy emphasis on sons of timar-holders, was thus the most diverse of any sultan's.

The kanunname regulating timar bestowals, a collection of edicts dating from the 1530 s to the 1570 , controlled only the award of timars to the sons of sipahis and the larger grants given to officials, civil servants, and military officers. ${ }^{42}$ It took no account of other timar recipients and did not attempt to regulate the bestowal of timars on men from other military and state services or on sons of nobodies. Its aims seem to have been to limit the inheritance of timars or timar-holding status by sipahis' sons, to ensure that those gaining timars provided service, and to increase the difficulty of gaining a timar by impersonation. Thus, despite the favoring of timar-holders' sons under Süleyman, this kanunname testifies to his administration's firm control over them. A chronological analysis of its provisions suggests a gradual transformation

TT553 Bosna 973/1565, TT544 Haleb 973/1565, TT562 Karahisar-1 Şarki 973/1565, and TT212 Paşa 974/1566. For the extreme percentages see registers TT139 Aydın and TT197 Erzurum.

40 Kunt, İ. Metin, The Sultan's Servants: The Transformation of Ottoman Provincial Government, 1550-1650 (New York: Columbia University Press, 1983), pp. 64, 66. Cvetkova noticed this as well without quantifying it: Cvetkova, "Early Ottoman Tahrir Defters", p. 178.

41 There were three exceptions in the 23 registers studied: TT217 (six percent), Ruz.17 studied by Howard ( 26 percent), and тт 356 (ten percent). Also exceptional was the Malta Campaign Register of 972/1564 studied by Cassola, but it was exceptional on many counts. Thus, timar awards to administrative personnel did not disappear, as has been asserted; see Dávid, Géza, "Ottoman armies and warfare, 1453-1603", in The Cambridge History of Turkey, Volume 2, The Ottoman Empire as a World Power, 1453-1603, ed. Suraiya N. Faroqhi and Kate Fleet (Cambridge: Cambridge University Press, 2013), p. 287. According to Röhrborn, the chronicles state that vezirs and beys had hundreds of slaves and followers to whom they would have wished to award timars, but they do not appear in the icmal defterleri, although some of them may have been among the sons of nobodies; Röhrborn, Untersuchungen, pp. 64-73. His study amply testifies, however, to the fact that timar awards were undergoing change at this time.

Howard, "Ottoman administration and the Tîmâr system: Sûret-i Kânûnnâme-i 'Osmânî Beray-i Tîmâr Dâden", pp. 46-125. Copies (or versions) of the compilation date from the mid-sixteenth to the mid-seventeenth centuries. These edicts were quoted, when appropriate, in a number of the entries in the mühimme registers. 
of the sipahis from a warrior class to a landholding gentry and gives the impression that Süleyman (or his scribal corps) was in fact attempting to create a hereditary timar-holding class dependent on the sultan. This impression, however, depends on ignoring all the other men of different backgrounds who gained timars in this period. Such an attempt was not continued under his successors, who appear to have shifted their ambitions in the Mediterranean from conquest to legal domination at about the same time. ${ }^{43}$

This period, from the 1530 s to 1565 , was when the stereotypes and legends of the timar system developed in which timars were seen as the prerogative of sons of prior timar-holders and not to be given to outsiders, who were considered less capable and less devoted to the empire's success. ${ }^{44}$ Süleyman's prestige helped to classicize the system as it was configured during his reign, and his penchant for legislation wrote these decisions 'in stone' for later generations. In that way, a system designed for flexibility and expansion rigidified and became part of the Ottomans' early modern identity. The general population growth of the period affected the elites as well as villagers and townspeople. ${ }^{45}$ As more sons of sipahis competed for timars and more failed to acquire them, prejudice against including additional competitors naturally increased. Although as late as 1531 Süleyman had issued an edict forbidding anyone to harass or exclude those who were not the sons of timar-holders, in 1544 he had to change his tune, not eliminating outsiders completely but certainly not encouraging their appointment: "Now, it is not at all my order to grant timars to people from the reaya, garrison soldiers, or müsellems". 46 The retired grand vezir Lütfi Paşa in his nasihatname warned against giving timars to members of the reaya because the decrease in the number of peasants as everybody rushed to timar-holding status would lower the sultan's revenue. He clearly had no concept of population growth; even with the flood of rural people to the cities and the army, the agrarian population was still increasing. The new order did

43 On Ottoman ambitions in the Mediterranean see Gürkan, Emrah Safa, "Fooling the Sultan: information, decision-making and the Mediterranean faction: $\left(15^{8} 5^{-15} 87\right)$ ", Osmanlı Araştırmaları, 45 (2015), 57-96; White, Joshua M., Piracy and Law in the Ottoman Mediterranean (Stanford: Stanford University Press, 2017), pp. 3-4.

44 Káldy-Nagy, "The 'Strangers' (Ecnebiler)," pp. 165-9.

45 Goldstone, Jack A., Revolution and Rebellion in the Early Modern World (Berkeley: University of California Press, 1991); Barkan, Ömer Lütfi, "Essai sur les données statistiques des registres de recensement dans l'empire ottoman aux Xve et Xvie siècles", Journal of the Economic and Social History of the Orient, 1 (1958), 9-36; Cook, M.A., Population Pressure in Rural Anatolia, 1450-160o (London: Oxford University Press, 1972); Jennings, Ronald C., "Urban population in Anatolia in the sixteenth century: a study of Kayseri, Karaman, Amasya, Trabzon and Erzurum", International Journal of Middle East Studies, 7 (1976), 21-57. 
not prevent outsiders from gaining timars, but it did mean that their qualifications were carefully checked from then on.

Orders in the earliest surviving mühimme register (register of outgoing orders) of 1544-45 already begin to reflect the increased competition for $t i$ mars. A content analysis of all orders on timars in the published mühimme registers found in this register five orders on the sons of timar-holders commanding the provincial governors to write in their bestowal documents the date and circumstances of the death of the applicants' fathers, first to make sure that they were not still alive (when no timar would be awarded) and then to determine the number and size of timars allocated to their sons (deaths at home, on campaign, and in battle rated increasingly large awards). ${ }^{47}$ When the governor of Budin awarded timars to gönüllüs, he was told to send a separate petition specifying how many awards he was making, presumably to prevent false documents from being added to the stack. ${ }^{48}$ Several orders in the earliest register suggest a shortage of timar lands, including an order making timars from unsurveyed land, an attempt to use an initial timar to fulfill a petition for a raise, and the assignment of a timar worth less than a third of the amount granted. ${ }^{49}$ These examples testify to a noticeable crowding in the ranks of aspiring timar-holders by the 1540 . In 1558 the mühimme register showed 60 percent of entries on timar-holders reporting issues related to crowding in the ranks, primarily the making of timars out of ruined villages and disputes over existing timars. ${ }^{50}$ This number can be raised to over 90 percent by including entries complaining that sipahis had their timars taken away or were not given the timars that contained their homes, plus four that described people obtaining timars with false documents. Moreover, villages producing more than their surveyed amounts were usually taken for the sultan's has, while ruined or unproductive areas were given as timars in the hope that that the timarholders would do what was necessary to bring them back into production. ${ }^{51}$

47 Topkapı Sarayı Arşivi H.951-952 Tarihli ve E-1232ı Numaralı Mühimme Defteri, ed. Halil Sahillioğlu (Istanbul: IRCICA, 2002), \#37, \#321, \#322, \#406, \#526.

48 Topkapı Sarayı Arşivi H.951-952 Tarihli ve E-12321 Numaralı Mühimme Defteri, \#351. On gönüllüs see Fodor, Pál, "Making a living on the frontiers: volunteers in the sixteenthcentury Ottoman army", in Ottomans, Hungarians, and Habsburgs in Central Europe, ed. Géza Dávid and Pál Fodor (Leiden: Brill, 200o), pp. 229-64.

Topkapı Sarayı Arşivi H.951-952 Tarihli ve E-12321 Numaralı Mühimme Defteri, \#205, \#367, $\# 478$. These orders add up to about a third of the entries in the register that mention timars for any reason.

50 3 Numaralı Mühimme Defteri (966-968/1558-156o) (Ankara: T.C. Başbakanlık Devlet Arşivleri Genel Müdürlüğü, Osmanlı Arşivi Daire Bakanlığı, 1993), too many entries to list.

$5^{1}$ An example is an unnamed village in Erzurum sancak: 6 Numaralı Mühimme Defteri (972/1564-1565) (Ankara: T.C. Başbakanlık Devlet Arşivleri Genel Müdürlüğü, Osmanlı 
Some probably did, but others merely complained or robbed their neighbors and had their timars taken away.

At the end of Süleyman's reign the mühimme registers signal the appearance of new problems. In the register of $1564-65$, several entries complained of delays in the awarding of timars after a survey. More complaints of extortion by timarholders and officials began to appear, which suggests that prices had started to rise noticeably and that some timar-holders' incomes no longer met their expenses. ${ }^{52}$ The incidence of reports of oppression, crime, and rebellion was approximately double that of the next three published registers, although sipahis convicted of crimes or oppression had their timars taken away. The sancakbeys and their subaşıs, it seems, were often guilty of oppressing villagers or entering free (serbest) areas and extorting money under various pretexts. ${ }^{53}$ In the mühimme register of 1564-65 there were five cases of timars awarded through bribery or false documents; such cases are documented since at least the early sixteenth century. ${ }^{54}$ Two entries mentioned "outsiders" (ecnebi), the first use of the term in the published registers. One of these outsiders was a zeametholder with a berat for an area that turned out to be already occupied, which he claimed was a mistake, and the other entry listed 16 men in Rumeli who claimed to be sons of timar-holders but who had no witnesses to that fact. ${ }^{55}$

Several entries in the mühimme register from the following year $\left(1565^{-66)}\right.$ record the granting of timars to men returning from the battle of Malta. ${ }^{56}$ The Malta campaign register shows that no timars were awarded there to the sons of timar-holders; all went to the sultan's slaves, men from the provincial governor's forces, or the followers of vezirs and other great men. ${ }^{57}$ Four entries

Arşivi Daire Bakanlığı, 1995), \#26o. The logic may have been that villages in the sultan's has needed to be productive and peaceful because they lacked continuous supervision, while those with more problems at least had timar-holders in residence. This practice is said to have started during Mehmed II's reign; Cvetkova, "Early Ottoman Tahrir Defters", pp. 171-3, 180 .

$5^{2} 6$ Numaralı Mühimme Defteri, for example \#187, \#650, \#66o. Mustafa Ali noted this as well: Mustafa Ali, Counsel for Sultans, p. 54.

53 See also Moačanin, Nenad, Town and Country on the Middle Danube, 1526-169o (Leiden: Brill, 2006), pp. 31, 121-2.

54 Cvetkova, "Early Ottoman Tahrir Defters", p. 181, n. 115.

556 Numaralı Mühimme Defteri, bribery: \#1463, \#1473; false documents: \#633, \#743, \#883; outsiders: \#1458, \#1185.

$56 \quad 5$ Numaralı Mühimme Defteri (973/1565-1566) (Ankara: T.C. Başbakanlık Devlet Arşivleri Genel Müdürlüğü, Osmanlı Arşivi Daire Bakanlığı, 1994), \#546, \#547, \#549, \#594, \#644.

57 Cassola, Arnold, with İdris Bostan and Thomas Scheben, The 1565 Ottoman Malta Campaign Register (Malta: Publishers Enterprises Group, 1998); Darling, Nasîhatnâmeler I, pp. 220-1. 
complained about outsiders in the timar system. Since in the same year a register was issued for Karahisar-1 Şarki showing 69 percent of timars being given to men with no title or patronymic, this number of complaints seems remarkably small. One incident (two entries) concerned men with timars or garrison positions obtained under false pretenses despite the fact that twice their positions were taken away and awarded to others; another complained about a castle warden who took people's timars away and gave them to others with no right to them; and the third, lodged by the son of a deceased timarholder, reported a man who was not the son of a sipahi obtaining a timar with another's berat. ${ }^{58}$ One last entry described a janissary awarded a timar worth 12,000 akçes whose berat, upon inspection, mysteriously stated his award as 22,000 akçes. ${ }^{59}$ The impression these registers leave, unlike the earlier ones, is less of overcrowding and more of a growing financial need or greed on the part of the timar-holders. ${ }^{60}$ The debasement of the coinage in the following year suggests that prices were rising and that timar-holders may have been having greater difficulty meeting their expenses. We do not know the extent to which the government tried to ameliorate that deficit, or to whom.

\section{The Post- Süleymanic Timar System, Two Different Stories}

The period after the death of Süleyman has long been considered the era of the timar system's decline, an idea drawn from the nasihatnameler, works of political advice written during an era when most of the sultans were young, mad, or uninterested in ruling and appeared particularly in need of advice. The analysis and advice in these works, however, were geared to immediate problems and presented a rather myopic perception of the system as a whole. The data in the icmal defterleri both help explain why the authors complained of decline and provide evidence for revising their verdict over the longer term. The question then becomes how to revise it. This section provides two analytical alternatives, a short-term version which continues the narrative by sultanic reign, and then a longer-term view, a narrative by $5^{0}$-year periods, as employed

585 Numaralı Mühimme Defteri, \#204, \#223, \#256, \#1229. All these complaints came from central and eastern Anatolia, but none from Karahisar-1 Şarki.

595 Numaralı Mühimme Defteri, \#1779.

6o İnalcık, Halil, "Military and fiscal transformation in the Ottoman empire, 1600-1700", Archivum Ottomanicum, 6 (1980), 283-337. Complaints of oppression decreased in this register after the rise of the previous year, which goes against the trope of ever-increasing oppression. 
in my previous articles. As we will see, these two periodizations lead to quite different conclusions regarding what was happening to the timar system in the late sixteenth century.

Under Selim II (1566-1574) the predominance of the sons of timar-holders was lost, but that of the sons of nobodies was reinforced. ${ }^{61}$ In the icmal defterleri of his period, sons of timar-holders dropped to 20 percent, while sons of nobodies increased to 61 percent. Men of the devşirme received fewer timars, four percent rather than six. The provincial military stayed about the same, while administrative personnel and followers of great men lost ground, contrary to the usual assumption of growth in timars granted to court and governmental personnel. ${ }^{62}$ The mühimme register for the years $1567-69$ confirms that the competition for timars continued to intensify and that timar revenue was increasingly insufficient; several orders indicate that despite the new regulations, people were gaining timars under false pretenses, either by impersonation (including dressing as janissaries), ${ }^{63}$ or by falsifying documents. ${ }^{64}$ In several cases, people enlarged their timars through various strategems. ${ }^{65} \mathrm{~A}$ few people illegally acquired orders to receive two timars, or a timar and a salary. 66 One report states that some timar-holders on the road were killed and their berats stolen, another that for fear of such an occurrence some awardees refused to go to the Porte to obtain their berats. ${ }^{67}$ In order to prevent such behaviors, the timar award process was more closely regulated. ${ }^{68}$ Reports of crime and oppression involving timar-holders were relatively fewer in this register, but

61 Registers employed for Selim II's reign are TT471 Teke 976/1568, тт258 Manisa 980/1572, and тт677 Mezistre 981/1573.

62 Darling, "Nasihatnameler I", pp. 220-1. Mühimme register 13 dated 978/1570, which contains orders for timars resulting from the Cyprus campaign, shows 21 percent of timar recipients as sons of timar-holders, 34 percent as janissaries or çavuşes, and 31 percent as sons of nobodies; the number of janissaries grew enormously, while the sons of nobodies, though still substantial, were cut in half.

637 Numaralı Mühimme Defteri (975-976/1567-1569) (Ankara: T.C. Başbakanlık Devlet Arşivleri Genel Müdürlüğü, Osmanlı Arşivi Daire Bakanlığı, 1998), \#79, \#89.

647 Numaralı Mühimme Defteri, \#363, \#495, \#974, \#1353, \#1522, \#1957, \#2589. Clearly, this was a bigger problem than ecnebis, although even seven cases per year is not a large number for the entire empire.

657 Numaralı Mühimme Defteri, \#957, \#2153, \#2154, \#2646, \#2649, \#2650.

667 Numaralı Mühimme Defteri, \#91, \#1968, \#2198, \#2565.

677 Numaralı Mühimme Defteri, $\#_{2258}, \#_{2173}$.

687 Numaralı Mühimme Defteri, \#277, \#481, \#924, \#1327, \#1435, \#1685, \#1755, \#1824. Apparently the size of timars was reduced as well, in order to provide more of them; this might explain the reduction in cebelüs that the advice writers complain about. See Cvetkova, "Early Ottoman Tahrir Defters", p. 180. 
the persistent presence of those labeled ecnebi is suggested by references to what were called ecnebi timars. Three orders describe ecnebis receiving timars, in one case under the protection of emirs and alay beys. ${ }^{69}$ Three other orders command that ecnebis who received timars after the Nahçivan campaign should be dispossessed and replaced by the sultan's slaves and sekbans or by sons of sipahis who were on rotation out of their timars. ${ }^{70}$

Similar trends are visible in the mühimme register for $1570-72$, and some new problems emerge. ${ }^{71}$ The number of orders threatening to take timars away from their holders for oppression, crime, or dereliction of duty seems larger. Also larger is the number of men holding timar documents but unable to acquire vacant timars. ${ }^{72}$ The timars of two sancaks were all reportedly awarded to the sancakbey's men and those of another sancak to the sons of the surveyor, his scribe, and his chosen men, rather than to sons of timar-holders or men with orders for timars. ${ }^{73}$ Several orders reflect conflict between timar-holders and their sons waiting to become timar-holders, in one case leading to murder. ${ }^{74}$ Finally, there are several orders condemning deviations from the administrative procedures established under Süleyman. ${ }^{75}$

The major trends of Selim's reign were reversed under Murad III; the icmal defterleri show sons of timar-holders gaining greatly (40 percent), sons of nobodies down but still a substantial group ( 38 percent), and the other groups about the same low numbers. ${ }^{76}$ The high level of violence by this time among those unable to acquire a timar, or those whose income proved insufficient, suggests a situation with few alternatives. The sense of urgency is well reflected in the diatribes of Mustafa Ali. It was at this juncture that he wrote his scathing critique of the timar awards of $1580 .{ }^{77}$ It reflected the high proportion of

697 Numaralı Mühimme Defteri, \#341, \#974, \#1937. One ecnebi oğlu ecnebi became a notorious thief and was arrested (\#974).

$70 \quad 7$ Numaralı Mühimme Defteri, \#40, \#91, \#541.

7112 Numaralı Mühimme Defteri (978-979/1570-1572) (Ankara: T.C. Başbakanlık Devlet Arşivleri Genel Müdürlüğü, Osmanlı Arşivi Daire Bakanlığı, 1998).

7212 Numaralı Mühimme Defteri, \#347, \#662, \#837, \#871, \#915. Cvetkova noticed this also; Cvetkova, "Early Ottoman Tahrir Defters", p. 181.

7312 Numaralı Mühimme Defteri, \#347, \#548.

7412 Numaralı Mühimme Defteri, \#350, \#595, \#604.

7512 Numaralı Mühimme Defteri, \#604, \#662, \#701, \#1175.

76 Registers employed for Murad III's crucial reign are тт661 Novigrad 987/1579, TT59o Budin 988/1580, тт6o1 Kastamonu 99o/1582, тKMA333 Akşehir 991/1583, TKMA584 Beyşehir 991/1583, MAD 129 Mora 997/1588, тT765 İç İl 984/1576, тT613 Trabzon 992/1584, and A. $\{$ DFE.d.67 Kocaeli 1004/1595.

77 Mustafa Ali, Counsel for Sultans. 
timars granted to the sons of timar-holders during Süleyman's reign and the drop under Selim, but it showed no awareness of how recently that trend had taken hold or who the timar-holders were in other periods.

If we disaggregate the figures for Murad III's reign, 1580 does appear as a turning point, but not in the direction of Mustafa Ali's recommendations. In the later part of Murad's reign, the proportion of sons of timar-holders in the timar system dropped to only 26 percent, but the sons of nobodies went up to over 50 percent. Devşirme men decreased to six percent, provincial military men increased to six percent, and followers of men of state fell to just over one percent. This configuration matched neither Mustafa Ali's description of the problem nor his recommendation of solutions, which may help explain his failure to gain promotion; what he wrote was perhaps neither accurate nor helpful. The percentage of sons of sipahis holding timars was low, but that was probably because of the losses the Ottomans experienced in their war with the Safavids (1578-1590). ${ }^{78}$ However, seeing the large number of timars granted to men other that sipahis, Mustafa Ali concluded that the reason must be corruption of some sort, the granting of their rightful places to unworthy outsiders, when it was probably due more to the deaths of timar-holders, the inability to go on doubling the empire's size indefinitely, and a general unwillingness to displace Muslim landholders in the Arab lands, a conquest large in area but where the timar rewards were relatively small.

The mühimme register for 991/1583 held fewer complaints regarding timars in general, only three related to their bestowal, and no mention of ecnebis in the timar system at all. ${ }^{79}$ This was despite the fact that the icmal defterleri for that year showed large numbers of timars being granted to men who were not the sons of timar-holders. ${ }^{80}$ The war losses may have eased the pressure on timar awards, or perhaps the problem was not as dire as Mustafa Ali claimed. In addition, it appears that already in the 158 os the timar system was losing its centrality as the main route to high office at the political center: beginning in the 1580 s, as Metin Kunt showed, a growing number of high offices were awarded to men who had never been regular timar-holders. ${ }^{81}$ Career paths, in other words, were in the process of changing, and already before the military revolution the timar system was losing its former prestige.

\footnotetext{
$7_{8}$ See Kortepeter, Carl Max, Ottoman Imperialism During the Reformation: Europe and the Caucasus (New York: New York University Press, 1972).

79 Sultan'ın Emir Defteri (51 Nolu Mühimme), ed. Hikmet Ülker (Istanbul: Tarih ve Tabiat Vakfı Yayınları, 2003).

$80 \quad$ Darling, "Nasihatnameler I", p. 208, an average of 33 percent.

81 Kunt, The Sultan's Servants, pp. 64, 66.
} 


\section{Another View of the Problem}

Using a different chronology creates the possibility of a different narrative of the changes in the timar system. From the analysis above, organized by sultans' reigns, it would appear that each sultan had a different policy when it came to awarding timars, and that the prominence of sons of timar-holders, men of the devsirme, provincial military forces, and sons of nobodies changed with each reign. In that analysis, the problems of those seeking timars and not finding them determine the course of the narrative. Taking a longer view frees the analysis from sultanic policies and whims to follow the general trends independently of short-term fluctuations. If we group the calculations of timarholders' origins by half-centuries, a period that exceeds any sultan's length of reign, a very different picture emerges, one that provides even less support for the standard narrative based on the nasihatnameler. On this larger scale, the percentage of sons of timar-holders receiving timars did not change at 1580 , nor indeed throughout the late sixteenth and seventeenth centuries.

Over the long term, contrary to the opinions of authors such as Mustafa Ali and Koçi Bey, sons of timar-holders, sons and retainers of officials, and sons of nobodies gained timars in about the same proportions after the 1580 as before. The figures for sons of timar-holders remained remarkably stable. The registers studied yield an average of 42 percent of timar-holders as sons of prior timar-holders in the first half of the sixteenth century, 39 percent in the second half, 38 percent in the first half of the seventeenth century, and 37 percent in the second half. Given the warfare from 1565 on, both on the eastern and the western front, it is surprising that the awards to sons of timar-holders did not decrease far more. The change was unexpectedly minor, contradicting the legendary transfer of masses of timar revenue to the sultan's has or to officials and palace favorites that is repeated in almost every account of the timar system's "decline". ${ }^{2}$ The proportion of janissaries and palace staff also continued to decrease over time, as did the followers of great men; whoever the outsiders were who were supposed to be gaining timars in place of the sons of sipahis, in the long term they were emphatically not the protégés of the rich and powerful. The one group whose share of timars continued to rise in each half-century after 1400 was the sons of nobodies. Although their fathers had no names in the registers and could have been anonymous reaya, they and/or their fathers have

82 See, for example, Aksan, Virgina, "War and Peace", in The Cambridge History of Turkey, Volume 3, The Later Ottoman Empire, 1603-1839, ed. Suraiya N. Faroqhi (Cambridge: Cambridge University Press, 2006), p. 88. I here revise what I rashly wrote in the same volume in "Public finances: the role of the Ottoman centre", p. 120. 
been identified as coming largely from the lower military and administrative echelons, thus already servants of the sultan. They obtained their timars for the most part in the aftermath of military campaigns, where they had demonstrated their prowess on the battlefield and had been recommended for promotion when the sons of timar-holders were probably still at home. ${ }^{83}$

Ever since the fifteenth century the sons of nobodies had received between a fourth and a third of the timars, and in the late sixteenth century they obtained between a third and a half. That was an increase, but it was not the overturning of the timar system that the writers of nasihat proclaimed. And this increase was not across the board; in some provinces it was greater, in some provinces less, in some greater at one time and less at another; and in a few places the sons of nobodies held no timars at all. The highest figures come from Aydın, Manisa, Karahisar-i Şarki, Akşehir, and Beyşehir. The lowest figures come also from Aydın and Manisa, and from Haleb (ironically, since that was where Mustafa Ali claimed the problem was at its height), as well as Tırhala, Erzurum, İç Il, Bolu, and Diyarbakur. ${ }^{84}$ There is no particular geographical pattern to these figures, except that throughout the sixteenth century the extremes of high and low both occurred more often in Anadolu than in Rumeli. We cannot yet take such a close look at the later period.

Our ability to determine what happened in the seventeenth century is limited primarily by the preservation pattern of the icmal defterleri. In the Başbakanlık Arşivi there is a group of defters that runs up to $1628 .{ }^{85}$ There is also a group at the end of the century beginning in $1692 .{ }^{86}$ Between those dates there is one for Mosul in 1648, which does not appear to be a complete register;

83 Darling, "Nasihatnameler II", pp. 12-15; Howard, "The Ottoman Timar System", pp. 170-7.

84 Darling, "Nasihatnameler II", p. 27.

85 Registers employed for the first half of the seventeenth century are TT728 Bosna 1011/1602, TT730 Vidin 1011/1602, TT732 Kocaeli 1011/1602, TT735 Küdavendigar 1027/1617, A. \{DFE.d.81 Paşa 1038/1628. Most mid-century registers either cover fortress garrisons (omitted from this study) or contain no names.

86 Registers employed for the late seventeenth century are A.\{DFE.d.170 Kars 1104/1692, TT837 Kars 1104/1692, A.\{DFE.d.189 Bosna 1106/1694, and A.\{DFE.d.209 İnebaht1 1115/1703. Other registers for the late period contain no names. The figures in the seventeenthcentury registers for specific locations differ from those in registers with earlier dates, suggesting that they are independent counts and not mere copies. Even the ones that say "copy" (suret) appear to be copies of registers different from the earlier ones examined, perhaps lost registers. This was also noticed by Dávid and Fodor, "Changes in the structure", p. 165 . 
in Sofia there is one for Malatya and Maraş in $1661 .{ }^{87}$ As a result, for the seventeenth century we can as yet speak only in general terms. However, when the extant registers for that century are averaged together, they show that the sons of timar-holders received timars at about the same rate as in the late sixteenth century, 37 percent and 38 percent respectively. ${ }^{88}$ That rate did not change, so all the arguments about how the sons of timar-holders were being disadvantaged, how they were being shut out of timars by the corruption of officials who were awarding the timars to their own followers, were baseless rhetoric. It was simply not true. If there were timar-holders' sons without timars, it resulted most likely from population growth in the timar-holding class (which the Ottoman critics could not observe, lacking statistical tools), rather than from their deliberate exclusion.

Other groups, the sons and retainers of central and provincial military and civilian officials, did not hold large numbers of timars. All together, in the sixteenth century they averaged 16 percent of timars, in the early seventeenth century 12 percent, and in the late seventeenth century two percent, a steady decrease ${ }^{89}$ The late seventeenth-century figure includes a few people labeled as retirees, but there were no sons or retainers of central officials; in that period only sons and retainers of provincial officers received timars. The highest percentages of sons and retainers of officials in timars came in times of war. The diatribes about central officials getting their retainers timars in return for bribes, if not completely false, certainly described a problem of limited extent.

The sons of nobodies, however, are a different story. In the fifteenth century (in the registers examined) their proportion of timars was 23 percent, in the early sixteenth century 28 percent, in the later sixteenth century 38 percent, in the first quarter of the seventeenth century 45 percent, and in the late seventeenth century it rose to $5^{2}$ percent. It is possible, I suppose, that in later years the scribes of the timar registry grew more careless in recording the timar-holders' ancestry, but this comfortable idea is countered by the care taken in the new tahrirs that were made in the late seventeenth and eighteenth

87 These are registers A.\{DFE.d.1og in the Başbakanlık Osmanlı Arşivi and OAK 235/1 in the Bulgarian National Library. The icmal defterleri in the Tapu ve Kadastro collection have not yet been available to me.

88 Darling, "Nasihatnameler II", pp. 12, 19. In some areas of the empire, timars seem to have become increasingly hereditary; Dávid and Fodor, "Changes in the structure", pp. 166-8. The opposite trend is observable in Aydın; see Howard, Douglas A., "Central and provincial administrative interaction in Timar bestowals in the early seventeenth century", in Decision Making and Change in the Ottoman Empire, ed. Caesar E. Farah (Kirksville mo: Thomas Jefferson University Press, 1993), pp. 85-6.

89 Darling, "Nasihatnameler II", p. 25. 
centuries. Like that of the retainers, the percentage of sons of nobodies receiving timars peaked in time of war, reaching 6o percent during the War of the Holy League. The identities of these "sons of nobodies" must be checked through other sources to see if they still came from the same origins as the earlier ones. However, their acquisition of increasing numbers of timars was a trend that, despite occasional dips, was observable from the fifteenth century on and was not a new phenomenon in the late sixteenth or the seventeenth century. The people who were dispossessed because of it were not the sons of timar-holders but the palace and administrative personnel, whose percentage of the total gradually dropped to zero. ${ }^{90}$ If there was a class struggle within the timar system, it was between different groups than we have thought, not between the timar-holders and the devşirme but between the palace and provincial elites and the sons of nobodies.

Beyond military prowess, an important reason for the growing willingness to accept sons of nobodies as timar-holders must have been the greater irrelevance of timar-holding to political ascendancy. Mühimme registers from the seventeenth century confirm the decreased significance of timars among the important affairs of the empire. ${ }^{91}$ The proportion of entries dealing with problems of timar-holding noticeably decreased, and orders regarding the routine functioning of the system virtually disappeared. The system, in other words, continued to function outside the view of the sultans and vezirs. In addition, the advice writers became progressively more silent about timar awards. There was also no mention of ecnebis in these registers. The "reform" of the timar system in 1632 consisted of regularizing the award of timars to outsiders, and an advice work written around the time of the last published mühimme register did not even mention the timar system as a problem. ${ }^{92}$ Although timars were as numerous as in the sixteenth century, their role in imperial governance had radically changed.

$90 \quad$ Darling, "Nasihatnameler II", p. 31.

91 See 82 Numaralı Mühimme Defteri (1025-1027/1617-1618) (Ankara: T.C. Başbakanlık Devlet Arşivleri Genel Müdürlüğü, 200o); 83 Numaralı Mühimme Defteri (1036-1037/1626-1628) (Ankara:T.C. Başbakanlık Devlet Arşivleri Genel Müdürlüğü, 2001);85 Numaralı Mühimme Defteri (1040-1041/1630-1631) (Ankara: T.C. Başbakanlık Devlet Arşivleri Genel Müdürlüğü, 2002); Mühimme Defteri 9o, ed. Mertol Tulum (Istanbul: Türk Dünyası Araştırmaları Vakfı, 1993) dated 1056/1646-47.

92 Howard, “The Ottoman Timar System", pp. 193-235; Katip Çelebi, Haci Halife, Düstûru'lamel li-lslahil-halel, in Ayn-i Ali Efendi, Kavânîn-i Âl-i Osman der hülâsa-i mezâmin-i defter-i dî̀ân, ed. M.T. Gökbilgin (Istanbul, Enderun Kitabevi, 1979), pp. 119-40; Bozuklukların Düzeltilmesinde Tutulacak Yollar (Düstûru'l-amel li-ıslahil-halel), tr. Ali Can (Ankara, Kültür ve Turizm Bakanlığı, 1982). 
There is another relevant complaint in the nasihatnameler, and it is one that the icmal defterleri cannot tell us about. That element is the timars that were notoriously awarded as paşmaklık to harem women or as arpalık to officials. Since these people did not have provincial duties, they were not usually included in the provincial registers, and the icmal registers generally omit their timars. What the icmals can do is to determine the size of the problem. Subtracting the number of timars in registers after the 1580 s from the number listed before that date should yield a rough idea of how many timars were removed from the provincial timar system for award to noncombatants. ${ }^{93}$ Provincial studies differ on this issue; in both Aydın and Vidin between 1580 and 1632 the number of timars decreased, but in Aydin this decrease was a drastic $5^{2}$ percent and in Vidin it was a moderate ten percent. ${ }^{94}$ The archives contain icmal defterleri spanning the period around 1580 for 15 livas..$^{95}$ In these registers, the number of timars awarded to the provincial army decreased in six livas, remained the same in three, and increased in six. The total number of timars in these 15 livas did not fall, it grew. There is no single pattern to this growth; sometimes the numbers fell after a rise, sometimes there was a steady decline, sometimes a large increase, sometimes an incremental one. We clearly cannot generalize from the experience of a single province; the only general statement that can be made is that conditions were experienced differently in each province, and there was no one empire-wide trend. Again, further research in other sources is needed to flesh out this picture, but our notions about the decline of the timar system must be revised. In terms of numbers, the timar system was not diminished by the changes of the seventeenth century; the timar-holders did not disappear and were not replaced. The question of whether the size and value of the lands in the timar system remained the same demands a different study; indications are that it did not, but investigations so far have been confined to individual localities. This study shows that there were some areas where the number of timars decreased rapidly, and those lands may have gone to compensate their new recipients for the fluctuations in the value of their salaries. Once the currency stabilized, however, such lands may have been returned to the timar system, as the numbers from 1632 do not indicate a general long-term

93 If noncombatant timar-holders were required to provide men-at-arms, these timars may be listed; I thank the anonymous reviewer for this suggestion. I did not, however, see palace personnel holding timars or zeamets in the defters I examined. But I did not examine the has.

Howard, "The Ottoman Timar System", pp. 152, 158; Soyudoğan, "Reassessing the Timar System", p. 221.

Darling, “Nasihatnameler, II", pp. 6-8. 
reduction in timars. Unfortunately, we cannot yet say in detail what happened in the later seventeenth century; there are counts of timars in the works of Evliya Çelebi and Hüseyin Hezarfen, but they include additional elements such as garrison timars. ${ }^{96}$

Fortress garrison timars were not counted in my study. In fact, they were subtracted from the totals wherever possible and must be studied separately. ${ }^{97}$ The rise of urban garrisons in the seventeenth century and the strengthening of frontier fortresses on both east and west diverted a yet unknown portion of the timar stock to their support, vastly increasing the number of timars. For example, the liva of Erzurum had almost 2000 garrison timars and only a few hundred provincial (eşkinci) timars. ${ }^{98}$ If increasing numbers of Janissaries did receive timars, it may have been among the garrison forces. At the same time the average size of a timar, even those belonging to provincial timar-holders, seems to have decreased, and among the garrison forces even these smaller timars were shared by two to nine men. Simultaneously, the role of provincial timar-holders in the empire's protection and defense was reduced, though not eliminated. This change undoubtedly contributed to the anxiety over timars, as well as reducing the number of cebelüs or men-at-arms that a timar-holder brought to a campaign, another complaint of the early seventeenth century. ${ }^{99}$ A garrison soldier drawing income from a timar also had different responsibilities and outlook from a timar-holder stationed in the countryside. Rather than a decline, what can be seen here is the repurposing of the timar system to serve the needs of an empire with a stable frontier, an infantry army, and an unacceptable level of urban unrest. This revised timar system needs to be studied

96 Evliya Çelebi, Narrative of Travels in Europe, Asia, and Africa, in the Seventeenth Century, tr. Joseph von Hammer (London: Oriental Translation Fund of Great Britain and Ireland, 1834); Hezarfen Hüseyin Efendi, Telhîsül-Beyân fî Kavânîn-i Âl-i Osmân, ed. Sevim İlgürel (Ankara: Türk Tarih Kurumu, 1998).

97 See, for example, Oruç, Hatice, "1528/30 Tarihli Mücmel Tahrir Defterine Göre Bosna Sancağında Mustahfiz Timarları", in Perspectives on Ottoman Studies: Papers from the $18^{\text {th }}$ Symposium of the International Committee of Pre-Ottoman and Ottoman Studies (CIEPO) at the University of Zagreb, 2008, ed. Ekrem Čaušević, Nenad Moačanin, and Vjeran Kursar (Münster, Germany: LIT Verlag, 2010), pp. 743-61.

98 See тт76o dated 1049/1634.

99 See note 68. This result was also noticed by Dávid and Fodor, "Changes in the structure", pp. 170-8. They attribute the reduction in cebelüs to "the administrative reshaping of the empire" (p. 174), the strengthening of the beylerbeys (and to a lesser extent the sancakbeys) and their retinues vis-à-vis the ordinary timar-holders, and the simultaneous reduction in status and military effectiveness of the timar element compared to other components of the Ottoman army. 
in its own right, as an adaptation of an old socioeconomic institutions to new conditions, not as a symptom of imperial decay.

\section{Conclusion}

Rather than a universal decline of the timar system, we should see the changes of the late sixteenth and seventeenth centuries as a repurposing of the system to meet the altered needs of the later period. The people supported by timars in the seventeenth century were ordinary soldiers, garrison troops, and local notables. Timars no longer represented the route to high offices in the central government after the sixteenth century and were avoided by those with political ambitions; that is, the 'decline of the timar system' was a decline in political significance more than in functioning. It certainly did not disappear.

At least in the seventeenth century, timar-holders were important to the empire's identity and self-image, which as many scholars have shown was intimately tied up with kanun, the scribal corps, and the regulation of taxation and timar-holding. There was still a timar army drawn from the provinces. Although it is not yet clear what the seventeenth-century timar-holders did on their timars, they were mustered for campaigns, since they still had a military role in the siege warfare of the period as well as in the form of cavalry. If excused, they paid a fine, the bedel-i timar, which may have been used to hire specialized troops. ${ }^{100}$ The timars associated with the garrisons of frontier fortresses and urban citadels proliferated. In the first half of the seventeenth century, the number of timars did not decline; if anything, it grew. We do not yet have enough figures for the late seventeenth century to tell what happened then.

The sons of timar-holders did not lose their position in the timar system; it remained the same as before. The great loss of opportunity by timar-holders' sons was a false alarm, as their share of timars did not decrease significantly. The sixteenth-century scramble for timars occurred when the population desiring timars increased faster than the available timars, and it was neither the precursor nor the result of the corruption of the system, as the authors of advice so vehemently try to persuade us. Population reduction or the timar system's loss of political prestige brought it to an end. The sons and retainers of central government officials actually acquired fewer timars over time. The repurposing of the timar system in the seventeenth century did not make

100 Only one register of the bedel-i timar was found in the archives, so no comparisons could be made. This tax was probably farmed and might be found in the iltizam registers. 
timars disappear, but it made their status and centrality decline, at least from a central government point of view. The cavalry army and the timar system lost not so much their military role or their presence in the countryside but their role in governance and their prestige as a pathway to promotion to vizierial rank. Officials and their sons and retainers then chose a different route to high office, avoiding the timar system. Finally, once the primary weapon was no longer the cavalry bow, it no longer took a lifetime of training to become an expert warrior, and the sons of timar-holders lost their military advantage. The sons of nobodies became the mainstay of the timar system; by the end of the seventeenth century the sons of nobodies held over half the timars in the icmal defterleri, not counting those of the garrison troops. The timar system continued to exist into the eighteenth, nineteenth, and even the twentieth century, but it possessed a different character and has barely been studied in those periods with respect to the timar-holders. ${ }^{101}$

The 'decline' of the timar system may now be understood to mean the loss of its central position in Ottoman organization and of its iconic status as the characteristic form of Ottoman society. The 'post-classical' era, then, must be thought of as the era in which the Ottoman political, military, economic, and social systems were no longer unified or congruent and their regulation no longer formed the ideological center of Ottoman imperialism. The nasihatnameler reflected that process of reconceptualization even in their adherence to old values in the face of new demands and institutional transformations. Constructions of Ottoman history based on them, however, must be regarded as doubtful and subject to revision. Historicizing the timar system and the other imperial institutions is a step toward determining how their participants' experiences reflected or were connected to the historical changes of their periods.

101 Besides the article by Gradeva, "Between hinterland and frontier: Ottoman Vidin, fifteenth to eighteenth centuries", which reaches into the eighteenth century, see Mutafčieva and Dimitrov, Sur l'état du système des timars des XVIIe-XVIIIe ss.; Radushev, Evgeniy, "XVIIXVıII. Yüzyıllarda Osmanlı İmparatorluğu'nda Toprak Rejimi ve Osmanlı Askerî Nizamı", in CIÉPO: Comité international d'études pré-ottomanes et ottomans, VIIe symposium actes, ed. Jean-Louis Bacqué-Grammont, İlber Ortaylı, and Emeri van Donzel (Ankara: Türk Tarih Kurumu, 1994), pp. 299-304; Čar-Drnda, Hatidža, "Remnants of the Tîmâr system in the Bosnian Vilâyet in the second half of the nineteenth century", International Journal of Turkish Studies, 10/1-2 (Fall 2004), pp. 171-4; Clayer, Nathalie, "Note sure la survivance du système des timâr dans la region de Shkodër au début du xxe siècle", Turcica, 29 (1997), 423-31. 